\title{
Enzymatically hydrolysed protein and carbohydrate pools in deep-sea sediments: estimates of the potentially bioavailable fraction and methodological considerations
}

\author{
A. Dell'Anno ${ }^{1}$, M. Fabiano ${ }^{2}$, M. L. Mei $^{1}$, R. Danovaro ${ }^{1,3, *}$ \\ ${ }^{1}$ Institute of Marine Science, University of Ancona, Via Brecce Bianche, 60131 Ancona, Italy \\ ${ }^{2}$ Department for the Study of the Territory and its Resources, University of Genoa, Corso Europa 26, 16132 Genova, Italy \\ ${ }^{3}$ Department of Zoology, University of Bari, Via Orabona 4, 70125 Bari, Italy
}

\begin{abstract}
In this study we developed existing protocols for the enzymatic digestion of protein and carbohydrate pools in deep-sea sediments in order to estimate the organic fraction potentially bioavailable for benthic consumers. Sediment samples were collected in an abyssal locality (Porcupine Abyssal Plain, $4800 \mathrm{~m}$ depth) of the NE Atlantic in September 1996, and March and October 1997, and vertically divided into 5 layers dowm to a depth of $15 \mathrm{~cm}$. Protein and carbohydrate concentrations released enzymatically were highest after $2 \mathrm{~h}$ of incubation for both organic pools. The release of enzymatically hydrolysed proteins from the deep-sea sediments was significantly higher using Tris+EDTA and sonication instead of a simple sediment homogenisation in Na-phosphate buffer. Hydrolysed carbohydrate concentrations were higher utilising $\alpha$-amylase, $\beta$-glucosidase, Proteinase $\mathrm{K}$ and lipase instead of only $\alpha$-amylase and $\beta$-glucosidase. Hydrolysed proteins and carbohydrates accounted for a small fraction of the total protein and carbohydrate pools (on average 15 and $13 \%$, respectively), indicating that total protein and carbohydrate concentrations do not represent the actual available fraction of the sedimentary organic matter in this deep-sea environment. Hydrolysed protein pools changed significantly between sampling periods whereas carbohydrate pools appeared to be more conservative both spatially and temporally. Hydrolysed protein and carbohydrate concentrations were characterised by different vertical patterns and carbohydrate concentrations were much higher in deeper sediment layers. These results indicate that the 2 classes of organic compounds might play different roles in different sediment layers with important trophodynamic implications for benthic organisms living at different sediment depths.
\end{abstract}

KEY WORDS: Carbohydrates · Proteins - Deep-sea sediments · Enzymatic digestion

\section{INTRODUCTION}

Quantity and quality of organic matter (OM) in marine sediments are recognised as major factors affecting metabolism, distribution and dynamics of benthic organisms, from bacteria to megafauna (Grant \& Hargrave 1987, Graf 1989, Duineveld et al. 1997). Food availability in the sediments has long been expressed as the bulk concentration of organic carbon, nitrogen (by gas chromatography) or total OM (by ignition loss,

:E-mail: danovaro@popcsi.unian.it
Fabiano et al. 1995). However, the quantity of OM in marine sediments proved to be of very little significance in the assessment of the actual food availability to consumers (Newell \& Field 1983). Therefore, some authors have tentatively estimated the available fraction of sedimentary organic pools through the determination of the main biochemical classes of organic compounds (i.e., carbohydrates, proteins and lipids), which are assumed to be easier to digest and assimilate (Fichez 1991, Danovaro et al. 1993, Fabiano et al. 1995). George (1964) proposed an alternative approach for the assessment of the sedimentary organic 
matter actually available to benthic consumers, which is based on a simulated enzymatic digestion carried out in the laboratory. This approach has been adapted for analysing key molecules for trophodynamic studies in marine sediments, such as protein concentrations and amino acid bioavailability (Mayer et al. 1986, 1995).

In deep sea sediments, quantity and quality of $O M$ is largely dependent upon seasonal deposition of $O M$ produced in the photic layer and upon the complex biochemical transformations of the sinking particles occurring in the water column and at the deep ocean floor (Rice et al. 1986, Thiel et al. 1990, Santos et al. 1994). In this regard, labile OM such as proteins and sugars might become recalcitrant to degradation by complex interactions with sedimentary mineral particles and/or highly refractory organic compounds (Keil et al. 1994, Knicker \& Hatcher 1997). As standardised estimates of food availability in deep-sea sediments are essential parameters in trophodynamic studies (Danovaro et al. 1999a) and ecological modelling (Rice \& Rhoads 1989), there is a strong need for identifying universally accepted protocols for assessing the labile OM fraction.

However, a universally accepted method for assessing the labilie fraction of sedimentary OM does not yet exist. Despite this fact, a considerable effort has been made for the assessment of the readily available fraction of organic nitrogen in sediments (i.e., proteins and/or amino acids; Rice 1982, Mayer et al. 1986, 1993, 1995, Horsfall \& Wolff 1997); methods for discriminating the lability of other organic compounds (e.g., carbohydrates) are practically non existent (Buscail et al. 1995, Fabiano \& Danovaro 1998), Carbohydrate dominance among the main biochemical classes of $O M$ in the sediments has been reported as a specific feature of oligotrophic systems, including most deep-sea environments (Danovaro et al. 1993, Danovaro 1996).

The aims of the present study are: (1) to improve existing analytical protocols for the assessment of the potentially bioavailable protein fraction in deep-sea sediments by means of an enzymatic approach; (2) to propose a similar enzymatic approach for the digestion of sedimentary carbohydrate pools and (3) to investigate vertical and temporal changes of protein and carbohydrate pools hydrolysed enzymatically.

\section{MATERIALS AND METHODS}

Study area and sampling. Sediment sampling was carried out in the Porcupine Abyssal Plain (PAP; NE Atlantic at about $4800 \mathrm{~m}$ depth, $48^{\circ} 50.2^{\prime} \mathrm{N}, 16^{\circ} 29.9^{\prime} \mathrm{W}$ ). This area is characterised by high sedimentation rates (Newton et al. 1994) and a strong seasonality (Rice et al.
1994). Undisturbed sediment samples were collected using a multicorer (Mod. Maxicorer, $9.0 \mathrm{~cm}$ i.d., depth penetration $>20 \mathrm{~cm}$ ) on September 1996, March and October 1997. During each cruise, 4 to 10 cores were taken from 4 to 7 different deployments. Upon recovery all cores were vertically divided into 5 layers: $0-5$, $10-20,30-40,50-60$ and $100-150 \mathrm{~mm}$ and deep frozen at $-20^{\circ} \mathrm{C}$ until analysis.

Determination of potentially available proteins. The protocol proposed by Mayer et al. (1995) for protein enzymatic digestion in coastal sediments was applied to the deep-sea sediments collected in this study. However, whilst Mayer et al. (1995) measured amino acid concentrations released from sedimentary protein pools after enzymatic digestion, in this study we slightly modified Mayer's protocol by quantifying the amount of proteins after proteolytic attack. Frozen sediment samples were homogenised in $0.1 \mathrm{M} \mathrm{Na}$ phosphate buffer, ( $\mathrm{pH} 7.5$; sediment:buffer ratio of 2.5). In order to keep the total amount of proteins comparable between the different sediment layers, variable aliquots of sediment slurry were utilised: $0.5 \mathrm{ml}$ for surface and subsurface sediments $(0-5$ to $10-20 \mathrm{~mm})$ and $1.5 \mathrm{ml}$ for deeper sediments (down to $150 \mathrm{~mm}$ ). Replicate samples $(n=3)$ of each sediment layer (hereafter referred as 'treated samples') were added to $100 \mu$ of Proteinase $\mathrm{K}\left(1 \mathrm{mg} \mathrm{ml}^{-1}\right)$ and $100 \mu \mathrm{l}$ of protease $(600 \mu \mathrm{g}$ $\mathrm{ml}^{-1}$ ); another set of replicates was added to an equal volume of Na-phosphate buffer without enzymes (hereafter referred as 'control samples'). Enzyme characteristics and concentrations were chosen according to Mayer et al. (1986, 1995). Enzyme concentrations utilised in our time course experiments were calculated to be able to hydrolyse $1 \mathrm{mg}$ of bovine serum albumin $\mathrm{ml}^{-1}$ in about $10 \mathrm{~min}$. All samples were added with $\mathrm{Na}$-phosphate buffer to a final volume of $2 \mathrm{ml}$ and incubated at $37^{\circ} \mathrm{C}$ (as the optimal temperature for enzymatic activities) for 30,60 and $120 \mathrm{~min}$ under gentle agitation. After incubation, all sediment slurries were filtered onto GF/F filters and subsequently rinsed 2 times with $5 \mathrm{ml}$ of cold Na-phosphate buffer in order to remove the digested protein fraction and the enzymes from the sediments.

Proteins of all sediment samples were analysed spectrophotometrically according to Hartree (1972), modified by Rice (1982) to compensate for phenol interference. Protein concentrations were calculated from calibration curves of serum albumin (ranging from 2.5 to $50 \mu \mathrm{g} \mathrm{ml}^{-1}$ ). Differences between protein concentration of control and treated samples are assumed here to represent the concentration of proteins actually hydrolysed by proteolytic enzymes (hydrolysed proteins, HPRT). Preliminary analyses from sediment cores collected in September 1996 revealed that protein concentration in the pore water of the top 0 to 
$5 \mathrm{~mm}$ of the sediment was very low $\left(<5 \mu \mathrm{g} \mathrm{g}^{-1}\right.$ when normalised to sediment dry weight) and negligible when compared to the total sedimentary protein concentrations. Total protein concentrations from intact sediments (TPRT) and HPRT concentrations were normalised to sediment dry weight.

The above-described method was compared to the treatment conditions reported below to identify the most efficient protocol in protein digestion.

Subsamples, from the same frozen sediment cores utilised for the first treatment, were homogenised in $0.1 \mathrm{M}$ Tris, $0.1 \mathrm{M}$ EDTA (pH 7.5) containing $1 \mathrm{mM} \mathrm{DTT}$ (dithiothreitol; sediment:buffer ratio of 2.5) and sonicated 3 times for $1 \mathrm{~min}$ (with intervals of $30 \mathrm{~s}$ ) before enzyme addition. In order to verify that enzyme activity was not inhibited by such incubation conditions, additional subsamples were tested by adding leucine-MCA substrate (L-leucine-4-methylcoumarinyl-7amide, $200 \mu \mathrm{M}$ ) that proved the complete efficiency of the enzymatic pools (data not shown). Volumes of sediment slurries and enzyme concentrations were the same as those previously described, whereas incubation times were 20,40,60,90 and $120 \mathrm{~min}$. After incubation, all sediment slurries were filtered onto $G F / F$ filters and subsequently rinsed 2 times with $5 \mathrm{ml}$ of cold Tris $0.1 \mathrm{M}$ ( $\mathrm{pH} 7.5)$. The HPRT fraction was determined as described above.

Finally, this method of protein digestion was compared to the protein hydrolysis described by Mayer et al. (1986). This comparison was carried out only on sediment samples collected during October 1997.

Sediment subsamples muffled at $550^{\circ} \mathrm{C}$ for $4 \mathrm{~h}$ and processed as described above were utilised as blanks. Blanks treated and untreated with enzymes displayed very similar absorbance values, indicating that added enzymes were efficiently removed from sediment samples by filtration and rinsing.

Determination of potentially available carbohydrates. For enzymatic digestion of sedimentary carbohydrate pools, frozen sediment subsamples were homogenised with $0.1 \mathrm{M} \mathrm{Na-phosphate,} 0.1 \mathrm{M}$ EDTA (pH 6.9; sediment:buffer ratio of 2.5). Sediment slurries were sonicated 3 times for $1 \mathrm{~min}$ (with intervals of $30 \mathrm{~s}$ ) and divided into aliquots of $1.0 \mathrm{ml}$. Two different enzymatic pools were compared. The first was composed of $100 \mu \mathrm{l}$ of $\alpha$-amylase and $50 \mu \mathrm{l}$ of $\beta$-glucosidase. The second enzymatic pool was composed of $100 \mu$ l of $\alpha$ amylase, $50 \mu \mathrm{l}$ of $\beta$-glucosidase (as above) plus $100 \mu \mathrm{l}$ of Proteinase $\mathrm{K}$ and 100 hl of lipase. The stock solution of all enzymes was $1 \mathrm{mg} \mathrm{ml}^{-1}$. Another set of replicates treated by adding $0.1 \mathrm{M}$ Na-phosphate instead of enzyme solutions was utilised as control. The volume of all samples was adjusted to $2 \mathrm{ml}$ with $0.1 \mathrm{M} \mathrm{Na}$ phosphate. Samples were incubated for $10,60,120$, 240 and 360 min under gentle agitation at room tem- perature (as the optimal compromise of temperatures of $\alpha$-amylase, $\beta$-glucosidase and lipase producing the highest hydrolytic efficiency). Moreover, Proteinase $\mathrm{K}$ can also be routinely used at room temperature (Mayer et al. 1995). As for protein hydrolysis, sediment samples muffled at $550^{\circ} \mathrm{C}$ for $4 \mathrm{~h}$ and processed as described above were utilised as blanks. After incubation, all samples were centrifuged at $2000 \times g$ for $10 \mathrm{~min}$ and $1 \mathrm{ml}$ of the supernatant was utilised to determine carbohydrates released from the sediments. Soluble carbohydrates were determined from $1.0 \mathrm{ml}$ of the supernatant of the control sample. Carbohydrates from all supernatants $(1.0 \mathrm{ml})$ and from sediments (about $0.2 \mathrm{~g}$ added with $1.0 \mathrm{ml}$ of Milli-Q water) were analysed spectrophotometrically according to Dubois et al. (1956) and Gerchacov \& Hatcher (1972). Carbohydrate concentrations were calculated from calibration curves of D-glucose (range: 2.5 to $50 \mu \mathrm{g} \mathrm{m}^{-1}$ ). The actual fraction of hydrolysed carbohydrates $(\mathrm{HCHO})$ was obtained by calculating the difference between the carbohydrate concentrations determined in the supernatant of samples containing enzymes and the soluble fraction of the control. Total carbohydrate concentrations from intact sediments (TCHO) and $\mathrm{HCHO}$ concentrations were normalised to sediment dry weight.

\section{RESULTS}

\section{Estimates of hydrolysed proteins in deep-sea sediments}

Time courses of protein digestion of sediment samples incubated with and without enzymes (treated and control samples) and expressed as absorbance units at $650 \mathrm{~nm}$ are illustrated in Fig. 1. Absorbance yields significantly decreased with time both in control and treated sediment samples, reaching the lowest absorbance (i.e., the highest protein loss) at $2 \mathrm{~h}$. Therefore, it is possible to discriminate an apparent protein loss (decrease of the control absorbance) and an actual protein loss (the difference of absorbance between control and treated samples after $2 \mathrm{~h}$ ). The optimal incubation time for enzymatic protein digestion was $2 \mathrm{~h}$ as no further decrease was observed increasing the incubation time (i.e., $6 \mathrm{~h}$, data not shown) using both Na-phosphate and Tris-EDTA.

The efficiency of enzymatic treatment in protein digestion (expressed as the difference between control and treated samples after $2 \mathrm{~h}$ ) was 4 times higher in sediment samples homogenised in Tris-EDTA (Fig. 1b) than in Na-phosphate buffer (Fig. 1a).

The amount of hydrolysed proteins obtained using enzymatic pools in Tris-EDTA and $\mathrm{Na}$-phosphate is 

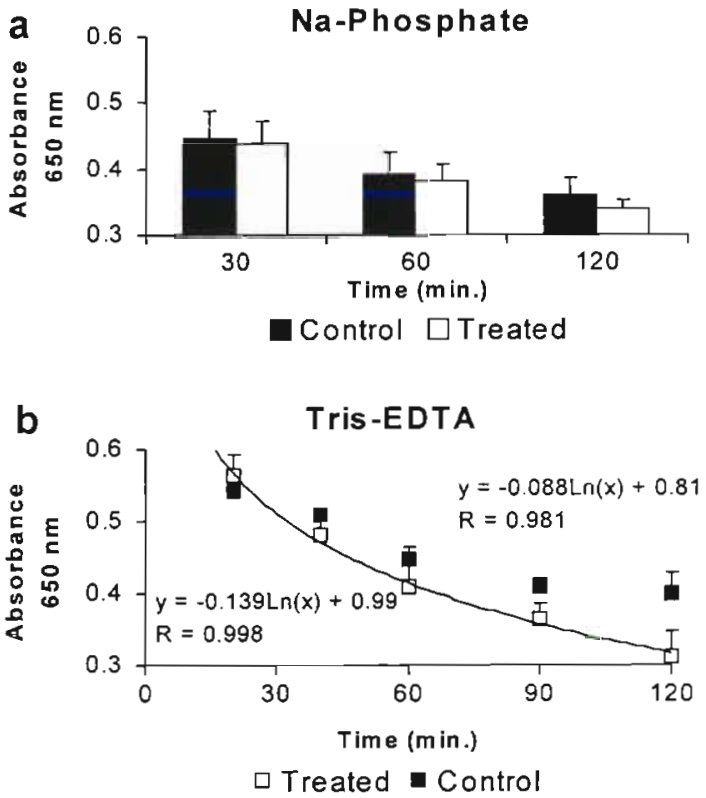

Fig. 1. Time course of enzymatic protein release in control and treated sediment samples. Protein release of sediment samples homogenised in (a) Na-phosphate and (b) Tris-EDTA. Standard deviations are reported (data are expressed as absorbance units at $650 \mathrm{~nm}$ )
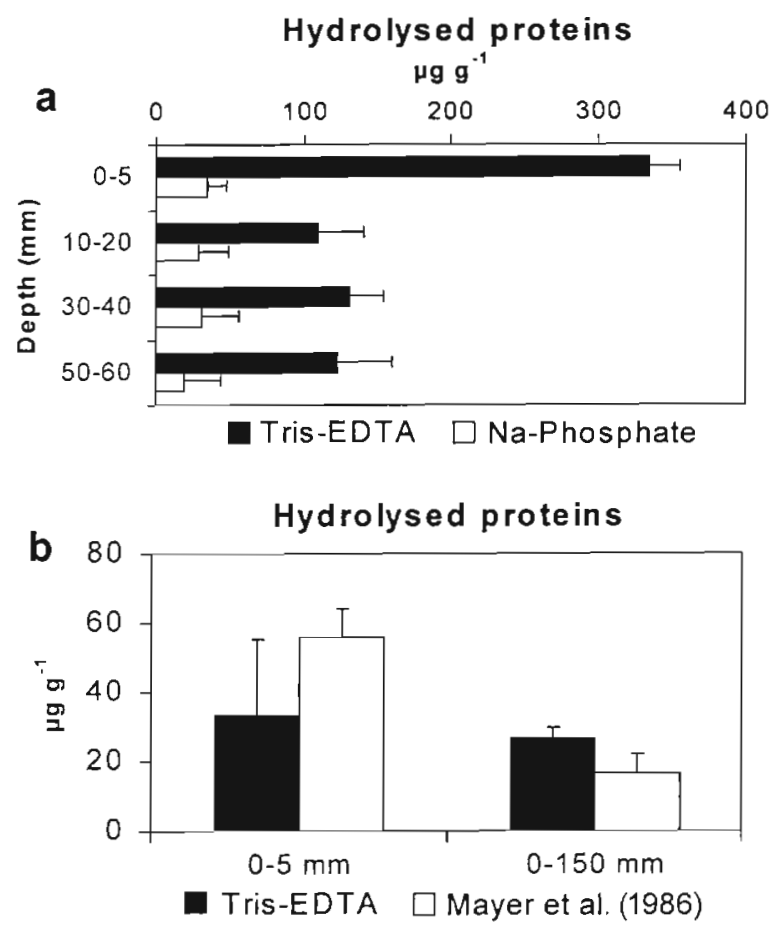

Fig. 2. Comparison of hydrolysed protein concentrations obtained utilising (a) Na-phosphate buffer and Tris-EDTA, (b) Tris-EDTA and the procedure of Mayer et al. (1986). Standard errors are reported
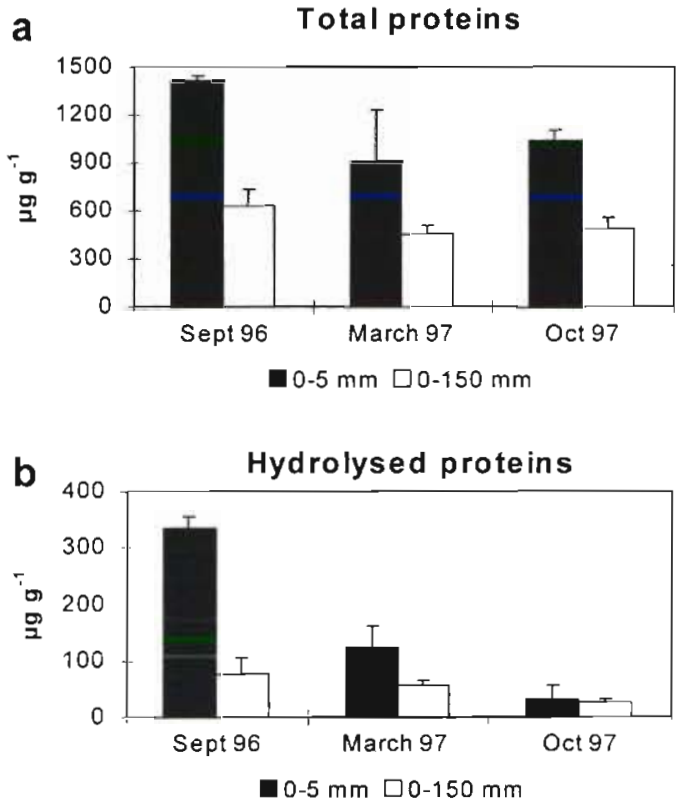

Fig. 3. Temporal changes in total protein concentrations (a) and hydrolysed fraction (b) in the top $0-5 \mathrm{~mm}$ of sediment and in the whole sediment core (i.e., $0-150 \mathrm{~mm}$ ). Standard errors are reported

compared in Fig. 2a. HPRT concentrations determined using Tris-EDTA were always significantly higher (up to 10 -fold) than those measured employing Na-phosphate buffer ( $t$-test; $t=13.9, \mathrm{p}<0.01$ ). As a consequence all further analyses were carried out using Tris-EDTA.

HPRT concentrations were not significantly different from protein concentrations obtained using the procedure of enzymatic hydrolysis of Mayer et al. (1986) $(t=-1.21, \mathrm{p}=0.22$ and $t=0.96, \mathrm{p}=0.21$ for the 0 to $5 \mathrm{~mm}$ and the whole sediment cores; Fig. 2b).

HPRT concentrations accounted on average for $15 \%$ of the TPRT pools in the upper sediment layer $(0$ to $5 \mathrm{~mm}$ ), decreasing to only $2 \%$ in the deeper sediment layers (e.g., 100 to $150 \mathrm{~mm}$ ).

Temporal changes in total and hydrolysed protein concentrations in the top $5 \mathrm{~mm}$ of the sediment and in the whole sediment core (integrated values 0 to $150 \mathrm{~mm}$ ) are reported in Fig. 3. HPRT concentrations were characterised by wider temporal changes than those observed for TPRT (highest to lowest ratio in surface sediments: 10 and 1.6 for HPRT and TPRT, respectively).

The analysis of the vertical profiles revealed that HPRT were characterised by a much stronger decrease with depth than TPRT (Fig. 4). 

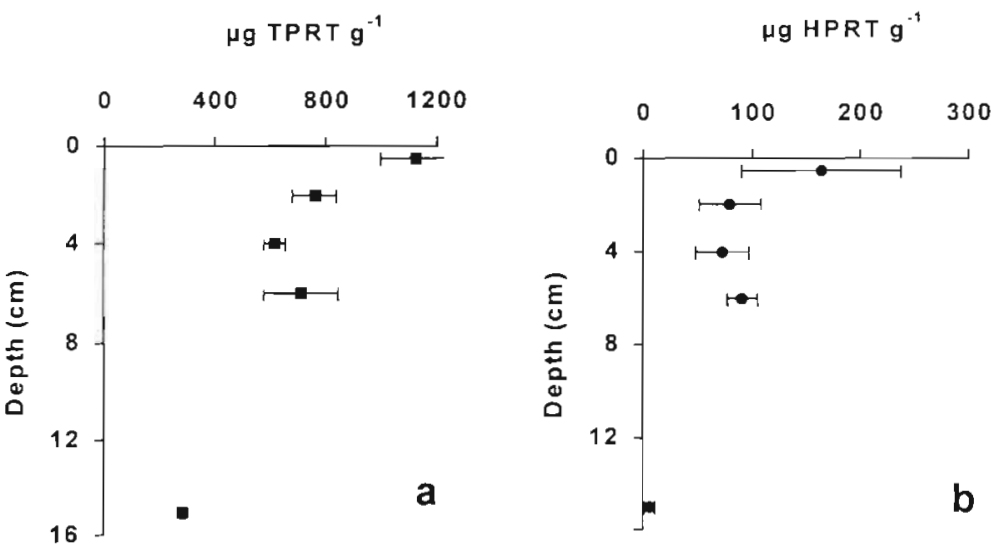

Fig. 4. Vertical distribution of (a) total protein concentration (TPRT) and (b) hydrolysed protein concentrations (HPRT). Average values of all sampled sediments at each depth and relative standard errors are reported

\section{Estimates of hydrolysed carbohydrates in deep-sea sediments}

Time course of carbohydrate release from the sediment into the supernatant (expressed as increase in absorbance at $490 \mathrm{~nm}$ ) proved a fast absorbance increase in the first $2 \mathrm{~h}$ followed by a lower release rate in the next $4 \mathrm{~h}$ (Fig. 5). Both controls and samples treated with enzymes released carbohydrates, but enzyme treatment significantly increased the amount of carbohydrates released in the supernatant. Moreover, the highest yields of hydrolysed carbohydrates (as the difference between treated and control) were obtained after $2 \mathrm{~h}$. Therefore, as for proteins, optimal incubation time for sedimentary carbohydrate digestion is $2 \mathrm{~h}$.

Hydrolysed carbohydrate concentrations obtained using the 4 enzymes were significantly higher than those obtained using only $\alpha$-amylase and $\beta$-glucosidase in the top $5 \mathrm{~mm}$ of sediment $(t=5.27, \mathrm{p}=0.017$,

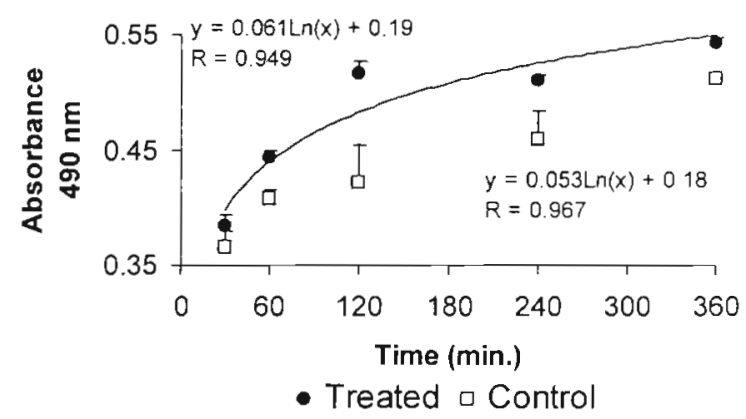

Fig. 5. Time course of enzymatic carbohydrate release in control and treated sediment samples (with $\alpha$-amylase, $\beta$-glucosidase, Proteinase $\mathrm{K}$ and lipase). Standard deviations are reported (data are expressed as absorbance units at $490 \mathrm{~nm}$ )
Fig. 6). Higher yields (though not significant, $t=0.68, \mathrm{p}=0.28$ ) were also obtained in the 100 to $150 \mathrm{~mm}$ layer. Therefore, the pool of 4 enzymes was routinely employed for carbohydrate digestion.

$\mathrm{HCHO}$ accounted on average for 13 and $10 \%$ of the TCHO pools in the top 0 to $5 \mathrm{~mm}$ and in the 100 to $150 \mathrm{~mm}$ sediment layer, respectively. Temporal changes in total and hydrolysed carbohydrates in the 0 to 5 and 0 to $150 \mathrm{~mm}$ layers of the sediment cores are reported in Fig. 7. TCHO and $\mathrm{HCHO}$ concentrations showed limited temporal changes. Total and hydrolysed carbohydrate concentrations barely decreased with depth in the sediment (on average for 25 and $40 \%$ from the $0-5$ to the 100-150 mm layer; Fig. 8).

\section{DISCUSSION}

Previous studies carried out in the PAP on surficial sediments showed evidence of TOC values typical of oxic abyssal sediments (ca $0.3 \%$ ), low values of the $\mathrm{C}: \mathrm{N}$ ratio (ca 5 to 8 ) and the presence of mixed marine

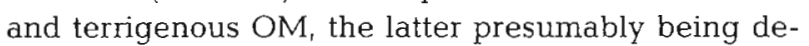
rived from higher plants and associated with the more recalcitrant fraction of sedimentary OM (Santos et al. 1994).

\section{Estimates of hydrolysed proteins and carbohydrates from deep-sea sediments}

Mayer et al. (1995) reported that the use of frozen or freeze-dried sediments for estimating bioavailable amino acids might significantly increase amino acid release in early stages of incubation. Such increase

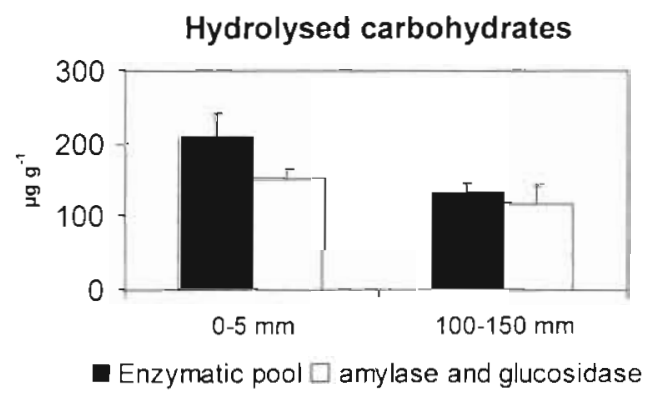

Fig. 6. Comparison of the hydrolysed carbohydrate concentrations obtained utilising only $\alpha$-amylase and $\beta$-glucosidase and the pool of the 4 enzymes ( $\alpha$-amylase, $\beta$-glucosidase, Proteinase $K$ and lipase) in the top $0-5$ and $100-150 \mathrm{~mm}$ of the sediment. Standard errors are reported 


\section{Total carbohydrates}
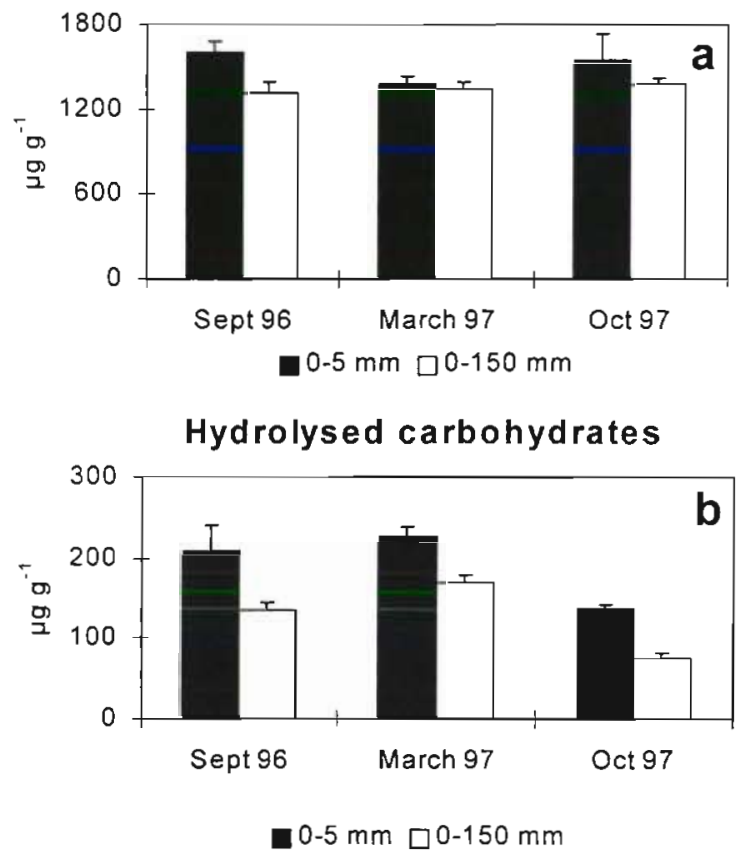

Fig. 7. Temporal changes in (a) total carbohydrate concentrations and (b) hydrolysed fraction in the top $0-5 \mathrm{~mm}$ of sediment and in the whole sediment core (i.e., $0-150 \mathrm{~mm}$ ). Standard errors are reported

could be due to the break-up of some sedimentary protective matrices (i.e., osmolytes, sensu Mayer et al. 1995), which provide a larger pool of substrates hydrolyzable by enzymes than the one available in fresh sediments. Freezing the sediments (e.g., $-20^{\circ} \mathrm{C}$ ) after collection is a common method of sample storage. All estimates reported here should be considered as measurements of the fraction potentially hydrolyzable of the protein and carbohydrate pools as: (1) enzymatic digestion was carried out on frozen sediment samples and (2) the optimal analytical conditions for maximising enzyme activities (i.e., temperature and $\mathrm{pH}$ ) were utilised.

In accordance with Mayer et al. (1995), we found a strong increase of the protein and carbohydrate release in the early phases of time course experiments. Enzyme-mediated protein and carbohydrate release from sediments, when normalised to the control, were highest after $2 \mathrm{~h}$ of incubation for both organic pools.

In this regard, it is important to stress the significance of the control samples, as these experiments proved that protein and carbohydrate pools are 'naturally' released in significant amounts from control samples during incubation. As cell lysis can account only for a completely negligible fraction of the carbohydrate and protein pools released (Danovaro et al. 1998), such release appears mainly to be due to desorption of $O M$ from exopolymers induced by sediment manipulation (Mayer et al. 1995).

In order to maximise the release of the hydrolysed protein pool from the deep-sea sediments, we utilised Tris+EDTA and sonication instead of a simple sediment homogenisation in Na-phosphate buffer as proposed by Mayer et al. (1995). Sonication and EDTA have proven to increase the extraction efficiency of different biochemical compounds (e.g., nucleic acids, proteins and carbohydrates) from deep-sea sediments (Danovaro et al. 1993, Dell'Anno et al. 1998). In accordance with our expectations we found that hydrolysed protein concentrations obtained by Tris+EDTA and sonication treatments were significantly higher than concentrations obtained utilising Na-phosphate buffer. The reasons for such increased yield are not completely clear, but since sedimentary $O M$ is largely bound to inorganic particles (Keil et al. 1994, Mayer 1999), it is possible that the increased hydrolysed protein pool depends on a facilitated interaction between substrate and enzymes. By contrast, no significant differences were found between hydrolysed protein concentrations measured with the present method and those determined according to Mayer et al. (1986). These results suggest that stronger pre-treatments of the sediments (i.e., using $\mathrm{NaOH}$ as described by Mayer et al. 1986 and Tris-EDTA as in the present study) enhance the efficiency of the enzymatic attack on the organic pools.

The processes described above (extraction efficiency, optimal temperature and incubation time) appear to be independent from the organic molecules investigated, as

Fig. 8. Vertical distribution of (a) total carbohydrate concentrations (TCHO) and (b) hydrolysed carbohydrate concentratjons (HCHO). Average values of all sampled sediments at each depth and relative standard errors are reported 
we obtained the same results for both protein and carbohydrate pools.

\section{Ecological significance of the hydrolysed organic pools}

In the PAP area, hydrolysed proteins and carbohydrates accounted only for a minor fraction (around 10 to $15 \%$ ) of their respective total pools. However, protein and carbohydrate pools displayed spatial and temporal differences.

In the top $5 \mathrm{~mm}$ of the sediment, HPRT concentrations accounted for $15 \%$ of the TPRT pools. Little information is available for comparison on the enzymatically hydrolysed protein pools and it must be considered that all existing data are from relatively shallow depths. Values reported in this study are lower than the enzymatically hydrolizable amino acids (EHAA) contribution to the total acid hydrolizable amino acids (TAHAA)' reported by Mayer et al. (1995) for an intertidal mudflat (on average $26 \%$ ), but match exactly those reported from an estuarine-shelf transect of the Gulf of Maine (on average 15\%; Mayer et al. 1986).

By contrast, no information is available on enzymatically hydrolysed carbohydrate pools in marine sediments; therefore, to our knowledge, these are the first data reported so far. $\mathrm{HCHO}$ concentrations were on average $13 \%$ of the TCHO pools in surface sediment layers. This value falls in the range of the soluble carbohydrate contribution to the total carbohydrate pools (TCHO) found in bathyal sediments of the Ross Sea (from 10 to $20 \%$ of the total sedimentary carbohydrate pools, Fabiano \& Danovaro 1998) and are about double those reported in deep-sea sediments of the highly oligotrophic Cretan Sea (about 6\%, Danovaro et al. 1998).

Previous studies have demonstrated that total protein and carbohydrate determinations in marine sediments reflect the material potentially available to consumers better than total organic carbon and nitrogen (Fabiano et al. 1995). However, these data indicate that TPRT and TCHO do not represent the actual available or digestible fraction of the sedimentary OM in the deep-sea sediments of the PAP area. Total protein and carbohydrate pools in surface sediments (i.e., 0 to $5 \mathrm{~mm}$ ) are ca 6 to 7 times higher than the enzymatically hydrolysed fraction, which generally is a rather constant fraction of the total pools.

From the linear regression between log-transformed HPRT and TPRT content $(\mathrm{n}=14, \mathrm{r}=0.733, \mathrm{p}<0.01$, Fig. 9), we found an intercept value of 2.22 , which was assumed to represent the non-enzymatically hydrolyzable protein fraction. This fraction accounted for about

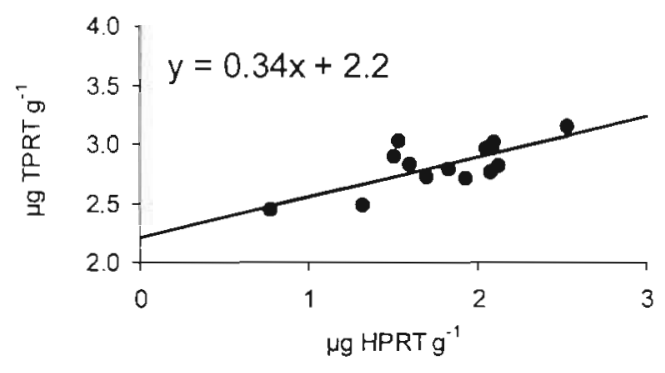

Fig. 9. Relationship between hydrolysed (HPRT) and total protein (TPRT) concentrations in the Porcupine Abyssal Plain sediments at each depth and for all sampling periods

$80 \%$ of the average TPRT concentration, indicating that, theoretically, about $20 \%$ of the TPRT pool is potentially available to consumers in the PAP sediments. Therefore, we might conclude that both analytical and theoretical estimates indicate that about 10 to $20 \%$ of the TPRT pool is potentially available to consumers.

HPRT concentrations were characterised by a much larger temporal variability than $\mathrm{HCHO}$. As particulate protein and carbohydrate inputs by sedimentation were very similar in quantity and temporal changes (Danovaro et al. 1999b), these data suggest that carbohydrates are more conservative than proteins. This is not surprising as proteins, which generally represent the limiting compound in most deep-sea environments (Danovaro et al. 1999a), are preferentially utilised by benthic organisms (Tenore 1988).

HPRT and HCHO concentrations were characterised by different vertical patterns. While HPRT concentrations strongly decreased with depth in the sediment (on average 25 times from the top 0 to $5 \mathrm{~mm}$ to 100 to $150 \mathrm{~mm}$ sediment layer), HCHO showed a highly conservative vertical pattern. These data indicate that the 2 classes of organic compounds might play different roles in different sediment layers. In surface sediments, HPRT and HCHO, expressed as carbon equivalents, displayed similar values (on average 80 and $77 \mu \mathrm{g} \mathrm{C} \mathrm{g}^{-1}$ as HPRT $\times 0.49$ and $\mathrm{HCHO} \times 0.40 \mu \mathrm{g} \mathrm{C}$ $\mu \mathrm{g}^{-1}$, Fabiano et al. 1995), whereas, in the deepest sediment layer, $\mathrm{HCHO}$ concentrations were 15 times higher than those reported for HPRT (3 and $45 \mu \mathrm{g} \mathrm{Cg}^{-1}$ for HPRT and $\mathrm{HCHO}$ ). These results might have profound implications in the benthic trophodynamics, as carbohydrates might represent the main food source for organisms living in the deeper sediment layers. Subsurface deposit feeders (which usually feed beneath the sediment mixing depth, i.e., ca 4 to $5 \mathrm{~cm}$ in the PAP sediments; Rabouille pers. comm.) are known to be constrained by lower amounts of available OM but according to the optimal foraging theory this is partially compensated by a diminished competition for 
available resources (Jumars \& Penry 1989). According to our results, subsurface consumers would also be subjected to a different diet regime characterised by the large predominance of carbohydrates and possibly different adaptive mechanisms to optimise the exploitation of this trophic source.

Further studies are needed to identify quantitative discrepancies between the potential and the actual amount of organic compounds effectively available to benthic consumers.

Acknowledgements. This work was carried out in the frame of the programme BENGAL: 'High resolution temporal and spatial study of the benthic biology and geochemistry of a north-eastern Atlantic abyssal locality', financially supported by EC funding under contract No. MAS3-CT950018 and MURST $40 \%$.

\section{LITERATURE CITED}

Buscail R, Pocklington R, Germain C (1995) Seasonal variability of the organic matter in a sedimentary coastal environment: sources, degradation and accumulation (continental shelf of the Gulf of Lions-northwestern Mediterranean Sea). Cont Shelf Res 15:843-869

Danovaro R (1996) Detritus-bacteria-meiofauna interactions in a seagrass bed (Posidonia oceanica) of the NW Mediterranean. Mar Biol 127:1-13

Danovaro R, Fabiano M, Della Croce N (1993) Labile organic matter and microbial biomasses in deep-sea sediments (Eastern Mediterranean Sea). Deep-Sea Res 40:953--965

Danovaro R, Marrale D, Della Croce N, Dell'Anno A, Fabiano M (1998) Heterotrophic nanoflagellates, bacteria and labile organic compounds in the continental shelf and deep-sea sediments of the E-Mediterranean. Microb Ecol 35:244-255

Danovaro R, Dinet A, Duineveld G, Tselepides A (1999a) Benthic response to particulate fluxes in different trophic environments: a comparison between the Gulf of LionsCatalan Sea (W-Mediterranean). and the Cretan Sea (EMediterranean) Prog Oceanogr 44:287-312

Danovaro R, Pusceddu A, Dell'Anno A, Bompadre S, Armeni M, Fiordelmondo C, Fabiano M (1999b) Labile organic matter (protein and carbohydrate) and phytopigment (HPLC) fluxes in the Porcupine Abyssal Plain. Final Report Bengal, Sauthampton Oceanographic Centre, Southampton, $\mathrm{p} 49-58$

Dell'Anno A, Fabiano M, Duineveld GCA, Kok A, Danovaro R (1998) Nucleic acid (DNA, RNA) quantification and RNAJDNA ratio determination in marine sediments: comparison of spectrophotometric, fluorometric and highperformance liquid chromatography methods and estimation of detrital DNA. Appl Environ Microbiol 64: 3238-3245

Dubois M, Gillesha K, Milton JK, Rebers PA, Smith F (1956) Colorimetric method for determination of sugars and related substances. Anal Chem 28:350-356

Duineveld GCA, Lavaleye MSS, Berghuis EM, Wilde PAWJ, Weele J, Kok A, Batten SD, Leeuw JW (1997) Patterns of benthic fauna and benthic respiration on the Celtic continental margin in relation to the distribution of phytodetritus. Int Rev Ges Hydrobiol 83:395-424

Fabiano M, Danovaro R (1998) Enzymatic activity, bacterial distribution, and organic matter composition in sediments of the Ross Sea (Antarctica). Appl Environ Microbiol 64: $3838-3845$

Fabiano M, Danovaro R, Fraschetti S (1995) A three-year time series of elemental and biochemical composition of organic matter in subtidal sandy sediments of the Ligurian Sea (North-Western Mediterranean). Cont Shelf Res 15: $1453-1469$

Fichez R (1991) Composition and fate of organic matter in submarine cave sediments; implications for the biogeochemical cycle of organic carbon. Oceanol Acta 14: 369-377

George JD (1964) Organic matter available to the polychaete Cirriformia tentaculata (Montagu) living in an intertidal mud flat. Limnol Oceanog 9:453-455

Gerchacov SM, Hatcher PG (1972) Improved technique for analysis of carbohydrates in sediments. Limnol Oceanogr $17: 938-943$

Graf G (1989) Pelagic-benthic coupling in a deep-sea benthic community. Nature 341:437-439

Grant J, Hargrave BT (1987) Benthic metabolism and the quality of sediment organic carbon. Biol Oceanogr 4 243-264

Hartree EF (1972) Determination of proteins, a modification of the Lowry methods that given a linear photometric response. Anal Biochem 48:422-427

Horsfall IM, Wolff GA (1997) Hydrolysable amino acids in surficial sediments from the Porcupine Abyssal Plain, northeast Atlantic Ocean. Organ Geochem 26:311-320

Jumars PA, Penry DL (1989) Digestion theory applied to deposit feeding. Ecology of marine deposit-feeders. In: Lopez $G$, Tagon G, Levinton J (eds) Lecture notes coastal and estuarine studies. Springer-Verlag, New York, p 114-128

Keil RG, Montlucon DB, Prahl FG, Hedges JI (1994) Sorptive preservation of labile organic matter in marine sediments. Nature 370:549-552

Knicker $H_{1}$ Hatcher PG (1997) Survival of protein in an organic-rich sediment: possible protection by encapsulation in organic matter. Naturwissenschaften 84:231-234

Mayer LM (1999) Extent of coverage of mineral surfaces by organic matter in marine sediments. Geochim Cosmochim Acta 63:207-215

Mayer LM, Schick LL, Setchell FW (1986) Measurement of protein in nearshore marine sediments. Mar Ecol Prog Ser 30:159-165

Mayer LM, Jumars PA, Taghon GL, Macko SA, Trumbore S (1993) Low-density particles as potential nitrogenous foods for benthos. J Mar Res 51:373-389

Mayer LM, Schick LL, Sawyer T, Plante CJ, Jumars PA, Self RL (1995) Bioavailable amino acids in sediments: a biomimetic, kinetics-based approach. Limnol Oceanogr 40:511-520

Newell RC, Field JG (1983) The contribution of bacteria and detritus to carbon and nitrogen flow in a benthic community. Mar Biol Lett 4:23-26

Newton PR, Lampitt RS, Jickells TD, King P, Boutle C (1994) Temporal and spatial variability of biogenic particle fluxes during the JGOFS NE Atlantic Process studies at $47^{\circ} \mathrm{N}$ $20^{\circ} \mathrm{W}$. Deep-Sea Res 41:1617-1642

Rice AL, Billett DSM, Fry J, Johns AWG, Lampitt RS, Mantoura RFC, Morris RJ (1986) Seasonal deposition of phytodetritus to the deep-sea floor. PIOC R Soc Edinb 88B: $265-279$

Rice AL, Thurston MH, Bett BJ (1994) The IOSDL DEEPSEAS programme: photographic evidence for the presence and absence of seasonal input of phytodetritus at contrasting abyssal sites in the north-eastern Atlantic Ocean. DeepSea Res 41:1305-1320 
Rice DL (1982) The detritus nitrogen problem: new observations and perspectives from organic geochemistry. Mar Ecol Prog Ser 9:153-162

Rice DL, Rhoads DC (1989) Early diagenesis of organic matter and the nutritional value of sediment. Ecology of marine deposit-feeders. In: Lopez G, Tagon G, Levinton J (eds) Lecture notes a coastal and estuarine studies. SpringerVerlag, New York, p 60-97

Santos V, Billett DSM, Rice AL, Wolff GA (1994) Organic matter in deep-sea sediments from the Porcupine Abyssal

Editorial responsibility: Otto Kinne (Editor),

Oldendorf/Luhe, Germany
Plain in the north-east Atlantic Ocean. I. Lipids. Deep-Sea Res 41:787-819

Tenore KR (1988) Nitrogen in benthic food chains. In: Blackburn $\mathrm{TH}$, Sorensen $\mathrm{J}$ (eds) Nitrogen cycling in coastal marine environment. Wiley, New York, p 191-206

Thiel H, Pfannkuche O, Shiiever G, Lochte $K_{1}$ Gooday AJ, Hemleben C, Mantoura RFC, Turley C, Patching JW, Riemann F (1990) Phytodetritus on the deep-sea floor in a central oceanic region of the north Atlantic. Biol Oceanogr $6: 203-239$

Submitted: June 29, 1999; Accepted: November 2, 1999 Proofs received from author(s): March 27, 2000 